December - 2009

\title{
Review of Distance Education Research (2000 to 2008): Analysis of Research Areas, Methods, and Authorship Patterns
}

\author{
Olaf Zawacki-Richter, Eva Maria Bäcker, and Sebastian Vogt \\ FernUniversität in Hagen (Germany)
}

\begin{abstract}
This paper presents a review of distance education literature to describe the status thereof and to identify gaps and priority areas in distance education research based on a validated classification of research areas. The articles $(N=695)$ published in five prominent distance education journals between 2000 and 2008 were reviewed for this study. The conclusion is that distance education research is strongly dominated by issues related to instructional design and individual learning processes; whereas, other important areas (e.g., innovation and change management or intercultural aspects of distance learning) are dreadfully neglected. There is a significant trend towards collaborative research and more qualitative studies. Over $80 \%$ of all articles originate from only five countries.
\end{abstract}

Keywords: Review of distance education research; research areas; Delphi study

\section{Research on Distance Education}

Research on distance education has been subject to harsh and consistent critique (Berge \& Mrozowski, 2001; Bernard et al., 2004; Perraton, 2000; Saba, 2000). Moore (1985) stated that there is "a massive volume of amateur, unsystematic, and badly designed research producing information of very little value" (p. 36). Panda (1992) analysed the Indian distance education literature and concluded that "most of the studies are either descriptive status surveys or experimental studies with poor methodological footing" (p. 322). Saba (2000) criticises the lack of theoretical underpinnings: "Research questions are rarely posed within a theoretical framework or based on its fundamental concepts and constructs" (p. 2). He is supported by Perraton (2000): "An examination of existing research shows that it is often atheoretical and predominantly descriptive" (p. 1). Is this really the case?

Lee, Driscoll, and Nelson (2004) emphasise that "understanding trends and issues in terms of topics and methods is pivotal in the advancements of research on distance education" (p. 225). The structure of a research discipline forms the foundation for identifying gaps and priority areas 
(Mishra, 1998, p. 281). Based on a validated classification of research areas in distance education through the systematic analysis of expert responses in a Delphi study (Zawacki-Richter, 2009), we conducted a literature review of previous distance education research published in five prominent distance education journals between 2000 and $2008(N=695$ articles $)$.

The aim of this paper is to address questions in the following three areas:

- Issues in distance education research: What are the main research areas in distance education and how have they changed between 2000 and 2008? What are the most common research areas and where are there gaps in distance education research?

- Research methods: Getting beyond the question of "any significant differences?" experts advocated more qualitative approaches in distance education research (Minnes, 1985; Saba, 2000). But can we observe a significant trend towards the application of more qualitative methods and mixed-methods designs (triangulation)? Is there an association between research methods and gender? And do distance education journals prefer to publish qualitative or quantitative studies?

- Publication and authorship patterns: Researchers are more and more often involved in complex international collaborative projects. Is there a significant trend towards more collaboration among researchers in distance education? Who are the leading contributors of research papers and where do they come from? Do distance education journals tend to publish papers from their country of origin?

Based on the review of research areas and trends, the results can be used to explore the body of knowledge in distance education and to identify priority areas for future research projects.

\section{Sample and Methods}

\section{Selection of Journals and Articles}

Five journals were reviewed for this study: Open Learning (OL), Distance Education (DE), the American Journal of Distance Education (AJDE), the Journal of Distance Education (JDE), and the International Review of Research in Open and Distance Learning (IRRODL). They were selected because of their reputations as the most prominent and recognized journals in the field of distance education. With the exception of IRRODL, which was released for the first time in 2000, the journals have been used as data sources in previous studies (cf. Berge \& Mrozowski, 2001; Lee, Driscoll, \& Nelson, 2004; Koble \& Bunker, 1997; Mishra, 1997; Rourke \& Szabo, 2002; Scriven, 1991). Furthermore, the five journals were selected because of their wide scope of distance education research in contrast to more specialized journals such as the Online Journal of Distance Learning Administration or the International Journal of Distance Education Technologies. 
All articles published between 2000 and 2008 in the five journals were reviewed $(N=695)$. Berge \& Mrozowski (2001) presented a large scale review with articles published between 1990 and 1999. Therefore, the year 2000 was chosen as the cut-off date for this study.

Twenty articles (2.9\%) were published in French (in the Journal of Distance Education) and 675 articles (97.1\%) were published in English.

Table 1

Data Sources

\begin{tabular}{llll}
\hline Journal & $\begin{array}{l}\text { No. of } \\
\text { articles }\end{array}$ & Percent & Volumes \\
OL & 154 & 22.2 & $15-23$ \\
DE & 156 & 22.4 & $21-29$ \\
AJDE & 112 & 16.1 & $14-22$ \\
JDE & 114 & 16.4 & $15-22$ \\
IRRODL & 159 & 22.9 & $1-9$ \\
Total & $\mathbf{6 9 5}$ & $\mathbf{1 0 0 . 0}$ & \\
\hline
\end{tabular}

\section{Classification of Research Areas}

In order to prepare this review, an international Delphi study was carried out in 2008 to develop a classification system for research areas in distance education. The Delphi technique was selected to develop a consensus among a group of experts on common areas that are or should be covered in distance education research. The essential element in the Delphi process is anonymity of participants when giving their opinion. The Delphi method, then, alleviates problems that could be caused by domination of the group by a few prestigious or powerful individuals (Charlton, 2004). According to Isaac and Michael (1995), the Delphi method of group interaction avoids the following disadvantages of face-to-face discussions: the bandwagon tendency, the vulnerability to manipulation, and the reticence on the part of individuals to change their minds in front of others. The final expert panel comprised 25 individuals from 11 countries (Australia, Brazil, Canada, China, Fiji, Germany, Ireland, New Zealand, South Africa, UK, and USA). Based on a literature review and a qualitative analysis of the responses from the panellists, three broad meta-levels of distance education research were derived:

1. macro level: distance education systems and theories,

2. meso level: management, organization, and technology,

3. micro level: teaching and learning in distance education.

Within these three levels, the research issues that are considered important by the experts can be categorized into 15 research areas. They are briefly characterized below. A detailed description of the method and the results of this pilot study is published in Zawacki-Richter (2009). 


\section{Macro level: Distance education systems and theories.}

1. Access, equity, and ethics: The democratization of access to distance education afforded by new media and by finding ways to deliver high-quality education to those who have limited resources and poor infrastructure; issues that refer to the (sustainable) provision of distance education in developing areas. What is the impact of distance education (e.g., via mobile learning) on narrowing the digital divide and what is the role of ICT (information and communication technologies) and/or OER (open educational resources) in terms of access to education?

2. Globalization of education and cross-cultural aspects: Aspects that refer to the global external environment and drivers, the development of the global distance education market, teaching and learning in mediated global environments, and the implications for professional development.

3. Distance teaching systems and institutions: Distance education delivery systems, the role of institutional partnerships in developing transnational programmes, and the impact of ICT on the convergence of conventional education and distance education institutions (hybrid or mixed-mode).

4. Theories and models: Theoretical frameworks for and foundations of distance education, e.g., the theoretical basis of instructional models, knowledge construction, interaction between learners, or the impact of social constructivism learning theories on distance education practice.

5. Research methods in distance education and knowledge transfer: Methodological considerations, the impact of distance education research and writing on practice, and the role of professional associations in improving practice. Literature reviews and works on the history of distance education are also subsumed within this area.

\section{Meso level: Management, organization, and technology.}

6. Management and organization: Strategies, administration, and organizational infrastructures and frameworks for the development, implementation, and sustainable delivery of distance education programmes. What is required for successful leadership in distance education? Distance education and policies relating to continuing education, lifelong learning, and the impact of online learning on institutional policies, as well as legal issues (copyright and intellectual property).

7. Costs and benefits: Aspects that refer to financial management, costing, pricing, and business models in distance education. Efficiency: What is the return on investment or impact of distance education programmes? What is the impact of ICT on the costing models and the scalability of distance education delivery? How can cost effective but meaningful learner support be provided?

8. Educational technology: New trends in educational technology for distance education (e.g., Web 2.0 applications or mobile learning) and the benefits and challenges of using OERs, media selection (e.g., synchronous vs. asynchronous media), technical infrastructure and equipment for online learning environments, and their opportunities for teaching and learning. 
9. Innovation and change: Issues that refer to educational innovation with new media and measures to support and facilitate change in institutions (e.g., incentive systems for faculty, aspects referring to staff workloads, promotion, and tenure).

10. Professional development and faculty support: Professional development and faculty support services as a prerequisite for innovation and change. What are the competencies of online teachers and how can they be developed?

11. Learner support services: The infrastructure for and organisation of learner support systems (from information and counselling for prospective students about library services and technical support to career services and alumni networks).

12. Quality assurance: Issues that refer to accreditation and quality standards in distance education. The impact of quality assurance and high quality learner support on enrolments and drop-out/retention, as well as reputation and acceptance of distance education as a valid form of educational provision.

\section{Micro level: Teaching and learning in distance education.}

13. Instructional design: Issues that refer to the stages of the instructional design process for curriculum and course development. Special emphasis is placed on pedagogical approaches for tutoring online (scaffolding), the design of (culturally appropriate) study material, opportunities provided by new developments in educational technology for teaching and learning (e.g. Web 2.0 applications and mobile devices), as well as assessment practices in distance education.

14. Interaction and communication in learning communities: Closely related to instructional design considerations is course design that fosters (online) articulation, interaction, reflection, and collaboration throughout the learning and teaching process. Special areas include the development of online communities, gender differences, and cross-cultural aspects in online communication.

15. Learner characteristics: The aims and goals of adult learners, the socio-economic background of distance education students, their different learning styles, critical thinking dispositions, and special needs. How do students learn online (learner behavior patterns, learning styles) and what competencies are needed for distance learning (e.g., digital literacy)?

All 695 articles published between 2000 and 2008 in the five journals (OL, DE, AJDE, JDE, and IRRODL) were coded according to this classification scheme. Table 2 provides an overview of sample studies. They are representative of a certain research area and research method.

\section{Classification of Research Methods}

The majority of distance education research can be classified broadly as quantitative, qualitative, or of mixed design (triangulation), which employs both quantitative and qualitative approaches. For this review the research methods were classified as quantitative, qualitative, triangulation, or other (cf. Grant, Ward, \& Rong, 1987). 
Articles that used statistical analysis were classified as quantitative, from simple methods such as chi-square analysis to multivariate techniques. Qualitative studies were data-based articles that did not quantify data beyond frequency counts. Included in this category were case studies, interpretive ethnographies, grounded theory, and phenomenological studies. Other articles were usually descriptive, not data-based, theoretical papers. 
Table 2

Matrix of Research Areas and Methods in Distance Education (Selection of Sample Studies)*

\begin{tabular}{|c|c|c|c|c|c|c|c|c|}
\hline Area** & Author(s) & Journal*** & Year & Vol. & Issue & Pages & Method & Description \\
\hline 1 & $\begin{array}{l}\text { Rye \& } \\
\text { Zubaidah }\end{array}$ & $\mathrm{OL}$ & 2008 & 23 & 2 & $\begin{array}{l}95- \\
102\end{array}$ & $\begin{array}{l}\text { Qualitative; } \\
\text { case study }\end{array}$ & $\begin{array}{l}\text { Study on access problems } \\
\text { in a master's programme } \\
\text { offered in a remote area of } \\
\text { Indonesia. }\end{array}$ \\
\hline 2 & Al-Harthi & IRRODL & 2005 & 6 & 3 & $\begin{array}{l}14 \\
\text { pp. }\end{array}$ & $\begin{array}{l}\text { Qualitative; } \\
\text { semi- } \\
\text { structured } \\
\text { interviews }\end{array}$ & $\begin{array}{l}\text { Phenomenological } \\
\text { research study on } \\
\text { experiences of Arab Gulf } \\
\text { students in the United } \\
\text { States taking online } \\
\text { courses. }\end{array}$ \\
\hline 3 & $\begin{array}{l}\text { Zhang \& } \\
\text { Shin }\end{array}$ & $\mathrm{OL}$ & 2002 & 17 & 2 & $\begin{array}{l}167- \\
176\end{array}$ & $\begin{array}{l}\text { Descriptive; } \\
\text { comparative }\end{array}$ & $\begin{array}{l}\text { Comparison of three open } \\
\text { and distance education } \\
\text { models in mainland } \\
\text { China, India, and Hong } \\
\text { Kong. }\end{array}$ \\
\hline 4 & $\begin{array}{l}\text { Garrison et } \\
\text { al. }\end{array}$ & AJDE & 2001 & 15 & 1 & $7-23$ & Theoretical & $\begin{array}{l}\text { A model of a community } \\
\text { of inquiry that constitutes } \\
\text { three elements essential to } \\
\text { an educational } \\
\text { experience: cognitive } \\
\text { presence, social presence, } \\
\text { and teaching presence. }\end{array}$ \\
\hline 5 & $\begin{array}{l}\text { Bernard et } \\
\text { al. }\end{array}$ & $\mathrm{DE}$ & 2004 & 25 & 2 & $\begin{array}{l}175- \\
198\end{array}$ & $\begin{array}{l}\text { Quantitative; } \\
\text { meta-analysis }\end{array}$ & $\begin{array}{l}\text { Suggestions for future } \\
\text { quantitative research, } \\
\text { especially with regard to } \\
\text { meta-analysis of distance } \\
\text { education vs. classroom } \\
\text { comparison studies. }\end{array}$ \\
\hline 6 & Jones & AJDE & 2008 & 22 & 1 & $46-56$ & $\begin{array}{l}\text { Triangulation; } \\
\text { survey and } \\
\text { qualitative } \\
\text { analysis of } \\
\text { interviews }\end{array}$ & $\begin{array}{l}\text { Survey on technology } \\
\text { usage and interviews with } \\
\text { directors on issues and } \\
\text { concerns regarding } \\
\text { institutional planning and } \\
\text { the introduction of online } \\
\text { learning. }\end{array}$ \\
\hline 7 & Jung & $\mathrm{OL}$ & 2005 & 20 & 2 & $\begin{array}{l}131- \\
146\end{array}$ & $\begin{array}{l}\text { Quantitative; } \\
\text { cost and cost } \\
\text { effectiveness } \\
\text { analysis }\end{array}$ & $\begin{array}{l}\text { Cost effectiveness study } \\
\text { of online teacher training. }\end{array}$ \\
\hline
\end{tabular}




\begin{tabular}{|c|c|c|c|c|c|c|c|c|}
\hline 8 & $\begin{array}{l}\text { Lee \& } \\
\text { Chan }\end{array}$ & $\mathrm{OL}$ & 2007 & 22 & 3 & $\begin{array}{l}201- \\
218\end{array}$ & $\begin{array}{l}\text { Triangulation; } \\
\text { survey and } \\
\text { qualitative } \\
\text { analysis of } \\
\text { semi- } \\
\text { structured } \\
\text { interviews }\end{array}$ & $\begin{array}{l}\text { Study on the effectiveness } \\
\text { and use of podcasts in } \\
\text { mobile learning. }\end{array}$ \\
\hline 9 & Shea et al. & IRRODL & 2005 & 6 & 2 & $\begin{array}{l}27 \\
\text { pp. }\end{array}$ & $\begin{array}{l}\text { Quantitative; } \\
\text { factor and } \\
\text { regression } \\
\text { analysis }\end{array}$ & $\begin{array}{l}\text { Article on potential } \\
\text { barriers to the continued } \\
\text { growth in adoption of } \\
\text { online teaching in higher } \\
\text { education. }\end{array}$ \\
\hline 10 & $\begin{array}{l}\text { Beyth- } \\
\text { Maron et } \\
\text { al. }\end{array}$ & IRRODL & 2006 & 7 & 2 & $\begin{array}{l}13 \\
\text { pp. }\end{array}$ & $\begin{array}{l}\text { Quantitative; } \\
\text { regression } \\
\text { and path } \\
\text { analysis }\end{array}$ & $\begin{array}{l}\text { Study on identification, } \\
\text { job satisfaction and work } \\
\text { motivation among tutors } \\
\text { at the Open University of } \\
\text { Israel. }\end{array}$ \\
\hline 10 & Mishra & $\mathrm{OL}$ & 2005 & 20 & 2 & $\begin{array}{l}147- \\
159\end{array}$ & $\begin{array}{l}\text { Triangulation; } \\
\text { ANOVA, } \\
\text { qualitative } \\
\text { analysis of } \\
\text { expert } \\
\text { responses }\end{array}$ & $\begin{array}{l}\text { Investigation of roles and } \\
\text { competencies of academic } \\
\text { counsellors in distance } \\
\text { education. }\end{array}$ \\
\hline 10 & Williams & AJDE & 2003 & 17 & 1 & $45-57$ & $\begin{array}{l}\text { Qualitative, } \\
\text { descriptive; } \\
\text { Delphi study }\end{array}$ & $\begin{array}{l}\text { Investigation of roles and } \\
\text { competencies needed in } \\
\text { distance education in } \\
\text { higher education } \\
\text { institutions and their } \\
\text { importance rated by } \\
\text { experts. }\end{array}$ \\
\hline 11 & Wang & IRRODL & 2005 & 6 & 3 & $\begin{array}{l}18 \\
\text { pp. }\end{array}$ & $\begin{array}{l}\text { Quantitative; } \\
\text { survey }\end{array}$ & $\begin{array}{l}\text { National survey } \\
\text { conducted in China to } \\
\text { examine learner and tutor } \\
\text { support systems. }\end{array}$ \\
\hline 12 & Giguère & JDE & 2007 & 22 & 1 & $19-40$ & $\begin{array}{l}\text { Quantitative; } \\
\text { regression } \\
\text { analysis }\end{array}$ & $\begin{array}{l}\text { Regression analysis used } \\
\text { to identify which of } 15 \\
\text { institutional factors } \\
\text { (independent variables) } \\
\text { were most strongly } \\
\text { associated with course } \\
\text { completion. }\end{array}$ \\
\hline 13 & $\begin{array}{l}\text { Morgan et } \\
\text { al. }\end{array}$ & $\mathrm{OL}$ & 2006 & 21 & 2 & $\begin{array}{l}167- \\
176\end{array}$ & $\begin{array}{l}\text { Triangulation; } \\
\text { survey } \\
\text { design, focus }\end{array}$ & $\begin{array}{l}\text { Guidelines for facilitating } \\
\text { online reflective learning } \\
\text { for health and social care }\end{array}$ \\
\hline
\end{tabular}




\begin{tabular}{|c|c|c|c|c|c|c|c|c|}
\hline & & & & & & & $\begin{array}{l}\text { group } \\
\text { discussion, } \\
\text { qual. analysis } \\
\text { of online } \\
\text { dialogue }\end{array}$ & professionals. \\
\hline 14 & Lara et al. & AJDE & 2001 & 15 & 3 & $50-67$ & $\begin{array}{l}\text { Triangulation; } \\
\text { qualitative } \\
\text { and } \\
\text { quantitative } \\
\text { analysis of } \\
\text { online } \\
\text { dialogue }\end{array}$ & $\begin{array}{l}\text { Analysis of synchronous } \\
\text { and asynchronous online } \\
\text { interaction patterns. }\end{array}$ \\
\hline 14 & Jeong & AJDE & 2006 & 20 & 4 & $\begin{array}{l}195- \\
210\end{array}$ & $\begin{array}{l}\text { Quantitative } \\
\text { analysis of } \\
\text { online } \\
\text { dialogue }\end{array}$ & $\begin{array}{l}\text { Message-response } \\
\text { analysis in computer- } \\
\text { mediated communication } \\
\text { to investigate gender } \\
\text { interaction patterns. }\end{array}$ \\
\hline 14 & $\begin{array}{l}\text { Moisey et } \\
\text { al. }\end{array}$ & JDE & 2008 & 22 & 2 & $15-42$ & $\begin{array}{l}\text { Quantitative; } \\
\text { correlational } \\
\text { design }\end{array}$ & $\begin{array}{l}\begin{array}{l}\text { Investigation of the } \\
\text { relationship between } \\
\text { community } \\
\text { (measured by Rovai's } \\
\text { classroom Community }\end{array} \\
\text { Scale), student } \\
\text { participation in computer- } \\
\text { mediated communication } \\
\text { and other variables } \\
\text { affecting community } \\
\text { building in online courses. }\end{array}$ \\
\hline 15 & $\begin{array}{l}\text { Muilenburg } \\
\& \text { Berge }\end{array}$ & $\mathrm{DE}$ & 2005 & 26 & 1 & $29-48$ & $\begin{array}{l}\text { Quantitative; } \\
\text { factor } \\
\text { analysis }\end{array}$ & $\begin{array}{l}\text { Exploratory factor } \\
\text { analysis that determined } \\
\text { the underlying constructs } \\
\text { that comprise student } \\
\text { barriers to online learning }\end{array}$ \\
\hline 15 & $\begin{array}{l}\text { Dearnley \& } \\
\text { Matthew }\end{array}$ & $\mathrm{OL}$ & 2000 & 15 & 2 & $\begin{array}{l}191- \\
206\end{array}$ & $\begin{array}{l}\text { Qualitative; } \\
\text { grounded } \\
\text { theory }\end{array}$ & $\begin{array}{l}\text { Exploration of student } \\
\text { experiences in distance } \\
\text { education. }\end{array}$ \\
\hline
\end{tabular}

* Full references for sample studies are provided in the appendix

** Research areas: $1=$ Access, equity and ethics; $2=$ Globalisation of education and cross-cultural aspects; $3=$ Distance teaching systems and institutions; 4=Theories and models; 5=Research methods in distance education and knowledge transfer; $6=$ Management and organisation; $7=$ Costs and benefits; $8=$ Educational technology; $9=$ Innovation and change; $10=$ Professional development and faculty support; 11=Learner support services; 12=Quality assurance; 13=Instructional design; 14=Interaction and communication in learning communities; 15=Learner characteristics *** Journals: $\mathrm{OL}=$ Open Learning; $\mathrm{DE}=$ Distance Education; AJDE=American Journal of Distance Education; $\mathrm{JDE}=$ Journal of Distance Education; IRRODL=International Review of Research in Open and Distance Learning 


\section{Inter-Rater Reliability}

Thirty articles were randomly selected to evaluate the coding decisions of the three coders (A, B and C) to determine inter-rater reliability using Cohen's kappa ( $\kappa)$ (Cohen, 1960), which is a coefficient for the degree of consistency among raters based on the number of codings in the coding scheme (Neumann, 2007, p. 326). Kappa values of .40 to .60 are characterized as fair, .60 to .75 as good, and over .75 as excellent (Fleiss, 1981; Bakeman \& Gottman, 1997).

Coding consistency for the classification of research methods between rater A and B was $\kappa=$ .855; between rater $\mathrm{A}$ and $\mathrm{C}$, it was $\kappa=.855$; and between rater $\mathrm{B}$ and $\mathrm{C}$, it was $\kappa=.930$ (median $=.855$ ). For the classification of research areas, coding consistency between rater $\mathrm{A}$ and $\mathrm{B}$ was $\kappa$ $=.672$; between rater $\mathrm{A}$ and $\mathrm{C}$, it was $\kappa=.675$; and between rater $\mathrm{B}$ and $\mathrm{C}$, it was $\kappa=.675$ (median $=.675)$. Therefore, inter-rater reliability can be considered as excellent for the coding of methods and as good for the coding of research areas.

The main source of coding discrepancies is the considerable overlap between some research areas so that a unambiguous classification of research areas was not easy in all cases. Some areas are investigated on different levels. Cross-sectional fields are those concerned with issues that refer to quality assurance and evaluation, educational technologies, and cross-cultural aspects (ZawackiRichter. 2009). For example, cross-cultural aspects have to be considered in international cooperation in the global education market (macro level) and in the planning, implementation, and management of transnational programmes (meso level). Cross-cultural aspects also have implications for competencies required by distance educators (professional development and faculty support - meso level). Intercultural communication plays an important role in classes with mixed cohorts of students from all over the world (micro level).

\section{Trend Analysis}

In order to identify significant trends between the years 2000 to 2008 in the development of research areas, in the application of research methods, and with regard to cooperation among researchers (single vs. multiple-author papers), the frequencies of research areas, methods, and number of authors in the 695 articles under review were ranked for each year and correlated with the years. Significant rank correlations on the $5 \%$ confidence level are interpreted as significant linear positive or negative trends. Due to the small number of years $(N=9)$, Spearman's rho $(\rho)$ was chosen as the non-parametric correlation coefficient.

\section{Results and Discussion}

\section{Analysis of Research Areas and Trends in Distance Education Research}

Table 3 reveals a strong imbalance of research areas covered in the publications: The microperspective (learning and teaching in distance education) is highly over-represented. Over $50 \%$ of 
all papers deal with the top three issues, i.e., interaction and communication in learning communities (17.6\%), instructional design (17.4\%), and learner characteristics (16.3\%).

Table 3

Ranking of Research Areas by Number of Articles by Research Area $(N=695)$

\begin{tabular}{llllll}
\hline Rank & Research Area & Level & F & \% & Cum. \% \\
\hline 1 & Interaction and communication in learning & 3 & 122 & 17.6 & 17.6 \\
& communities & & & & \\
2 & Instructional design & 3 & 121 & 17.4 & 35.0 \\
3 & Learner characteristics & 3 & 113 & 16.3 & 51.2 \\
4 & Distance teaching systems and institutions & 1 & 62 & 8.9 & 60.1 \\
5 & Educational technology & 2 & 48 & 6.9 & 67.1 \\
6 & Quality assurance & 2 & 41 & 5.9 & 72.9 \\
6 & Professional development and faculty support & 2 & 41 & 5.9 & 78.8 \\
7 & Access, equity and ethics & 1 & 31 & 4.5 & 83.3 \\
8 & Theories and models & 1 & 24 & 3.5 & 86.8 \\
9 & Learner support services & 2 & 23 & 3.3 & 90.1 \\
10 & Management and organisation & 2 & 18 & 2.6 & 92.7 \\
11 & Research methods in DE and knowledge transfer & 1 & 13 & 1.9 & 94.5 \\
11 & Globalisation of education and cross-cultural & 1 & & 13 & 96.4 \\
& aspects & & 1.9 & \\
11 & Innovation and change & 2 & 13 & 1.9 & 98.3 \\
12 & Costs and benefits & 2 & 12 & 1.7 & 100.0 \\
\cline { 2 - 6 } & Total & & 695 & 100. & \\
\end{tabular}

Level: 1=macro; $2=$ meso; $3=$ micro; $\mathrm{F}=$ frequency; $\mathrm{Cum} . \%=$ cummulative $\%$

No significant linear positive or negative trend of research issues can be reported for the period between 2000 and 2008. With only 13 articles in research area 5 (research methods in distance education), the number of articles increased slightly, but significantly, at a low level (Spearman's $\rho=.69, p<.05$ ). Research area 6 (management and organisation) is strongly correlated with area 7 (costs and benefits), $\rho=.88, p<.01$, which might indicate that these two categories could be merged.

Table 4 shows several noticeable peaks in certain research areas that were due to special issues on the topic, e.g., the special issue on "The Hybridzation of Higher Education: Cross National Perspectives" (area 3), edited by Peter S. Cookson in IRRODL (2002, Vol. 2, Issue 2), the special issue on "Challenges and Possibilities for Academics and Tutors at Open and Distance Learning Environments" (area 10), edited by Heather Kanuka in IRRODL (2006, Vol 7., Issue 2), the special issue on "Ethics in Open and Distance Learning" (area 1), edited by Anne Gaskell in Open Learning (2007, Vol. 22, Issue 2), and the special issue on "Technology, Policy, and the Right to Education” (area 1), edited by Barbara Spronk in IRRODL (2008, Vol. 9, Issue 1). 
Table 4

Frequency of Articles by Research Area between 2000 and $2008(N=695)$

\begin{tabular}{lllllllllll}
\hline $\begin{array}{l}\text { R. } \\
\text { area }\end{array}$ & 2000 & 2001 & $\mathbf{2 0 0 2}$ & $\mathbf{2 0 0 3}$ & $\mathbf{2 0 0 4}$ & $\mathbf{2 0 0 5}$ & $\mathbf{2 0 0 6}$ & $\mathbf{2 0 0 7}$ & $\mathbf{2 0 0 8}$ & Totals \\
\hline 1 & 2 & 1 & 2 & 0 & 3 & 5 & 0 & 7 & 11 & 31 \\
2 & 1 & 2 & 1 & 0 & 1 & 4 & 1 & 2 & 1 & 13 \\
3 & 1 & 13 & 15 & 1 & 3 & 9 & 3 & 8 & 9 & 62 \\
4 & 6 & 1 & 5 & 2 & 0 & 1 & 1 & 2 & 6 & 24 \\
5 & 1 & 1 & 1 & 1 & 2 & 2 & 1 & 2 & 2 & 13 \\
6 & 2 & 3 & 3 & 1 & 4 & 3 & 0 & 0 & 2 & 18 \\
7 & 2 & 2 & 3 & 0 & 3 & 2 & 0 & 0 & 0 & 12 \\
8 & 6 & 4 & 4 & 3 & 2 & 8 & 4 & 10 & 7 & 48 \\
9 & 4 & 1 & 0 & 1 & 0 & 3 & 2 & 1 & 1 & 13 \\
10 & 2 & 2 & 6 & 4 & 1 & 5 & 14 & 5 & 2 & 41 \\
11 & 2 & 3 & 0 & 6 & 5 & 3 & 2 & 2 & 0 & 23 \\
12 & 5 & 1 & 5 & 3 & 4 & 7 & 5 & 6 & 5 & 41 \\
13 & 14 & 11 & 15 & 12 & 10 & 8 & 22 & 14 & 15 & 121 \\
14 & 7 & 12 & 14 & 17 & 25 & 13 & 8 & 15 & 11 & 122 \\
15 & 17 & 12 & 13 & 11 & 13 & 8 & 19 & 6 & 14 & 113 \\
\hline Totals & 72 & 69 & 87 & 62 & 76 & 81 & 82 & 80 & 86 & 695 \\
\hline
\end{tabular}

*1=Access, equity and ethics; $2=$ Globalisation of education and cross-cultural aspects; $3=$ Distance teaching systems and institutions; 4=Theories and models; 5=Research methods in distance education and knowledge transfer; 6=Management and organisation; 7=Costs and benefits; 8=Educational technology; 9=Innovation and change; $10=$ Professional development and faculty support; 11=Learner support services; 12=Quality assurance; 13=Instructional design; 14=Interaction and communication in learning communities; 15=Learner characteristics

\section{Analysis of Research Methods}

Distance education, in particular, and the teaching and learning process, in general, are complex matters. Many variables are involved in instructional settings, not to mention other elements involved in distance education, such as social, organizational, technical, and global issues affecting the theory and practice in the field.

Getting beyond the question of "significant differences," experts make a plea for more qualitative approaches in distance education research (cf. Minnes, 1985; Saba 2000) to capture a deeper and richer range of data. Garrison and Shale (1994) make a case for mixed methods research: "Researchers are realizing that in practice the methodologies can be viewed as complementary ....Researchers who advocate combining quantitative and qualitative methods are thus on solid epistemological ground" (p. 25). The link between qualitative and quantitative research is therefore often termed triangulation (cf. Neumann, 2007, p. 149). This approach has the advantage that a complex research field such as distance education can be explored from different perspectives (or angles), utilizing different instruments and methods, and the data gathered can be used to mutually validate the results. 
However, what is the current status of the practice of distance education research? Table 5 shows the frequency tabulation regarding the methods applied in published studies. Interestingly there seems to be a trend towards more empirical research. Only $38.1 \%$ of all articles are descriptive in nature ("other") and $12.9 \%$ followed a mixed-method design (triangulation). However, this trend is not significant for the investigated period between 2000 and 2008 in the five journals. In contrast to the results of this study, Berge \& Mrozowski (2001) classified 75.9\% of articles published in journals as descriptive $(N=727$ articles; AJDE, DE, JDE, and OL between 1990 and 1999). In his review of 361 articles published between 1991 and 1996 in AJDE, DE, JDE, and the Indian Journal of Open Learning, Mishra (1997) reported the percentage of descriptive papers as 47.6.

Table 5 furthermore reveals that AJDE prefers quantitative studies: $63.4 \%$ of all articles published between 2000 and 2008 in AJDE followed a quantitative design. The journal that accepted by far the highest percentage of qualitative studies is DE $(29.5 \%)$. The journal with the most papers that applied a mixed-method approach is JDE (28.1\%). IRRODL (56.6\%) and OL (48.1\%) are the journals with the highest number of descriptive or theoretical papers ("other"). The association between journals and research methods is highly significant: $\chi^{2}=142.35, d f=12$, $p<.001$. However, the association is modest at Cramer's V of .26 $(p<.001)$.

Table 5

Cross Tabulation of Methods and Journals $(N=695)$

\begin{tabular}{lllllll}
\hline Method & OL & DE & AJDE & JDE & IRRODL & Total \\
\hline Quantitative & 33 & 42 & 71 & 27 & 29 & 202 \\
\% within Journal & $21.4 \%$ & $26.9 \%$ & $63.4 \%$ & $23.7 \%$ & $18.2 \%$ & $29.1 \%$ \\
Qualitative & 23 & 46 & 12 & 27 & 30 & 138 \\
\% within Journal & $14.9 \%$ & $29.5 \%$ & $10.7 \%$ & $23.7 \%$ & $18.9 \%$ & $19.9 \%$ \\
Triangulation & 24 & 11 & 13 & 32 & 10 & 90 \\
\% within Journal & $15.6 \%$ & $7.1 \%$ & $11.6 \%$ & $28.1 \%$ & $6.3 \%$ & $12.9 \%$ \\
Other & 74 & 57 & 16 & 28 & 90 & 265 \\
\% within Journal & $48.1 \%$ & $36.5 \%$ & $14.3 \%$ & $24.6 \%$ & $56.6 \%$ & $38.1 \%$ \\
\hline Total & 154 & 156 & 112 & 114 & 159 & 695 \\
\% within Journal & $100.0 \%$ & $100.0 \%$ & $100.0 \%$ & $100.0 \%$ & $100.0 \%$ & $100.0 \%$ \\
\hline
\end{tabular}

No significant trend towards more quantitative or mixed research designs or fewer descriptive studies can be reported (quantitative methods: Spearman's $\rho=-.43, p=.250$; triangulation: $\rho=$ $.10, p=.796$; other: $\rho=.24, p=.542)$. However, there is a significant positive trend towards more qualitative research $(\rho=.73, p<.05)$. 


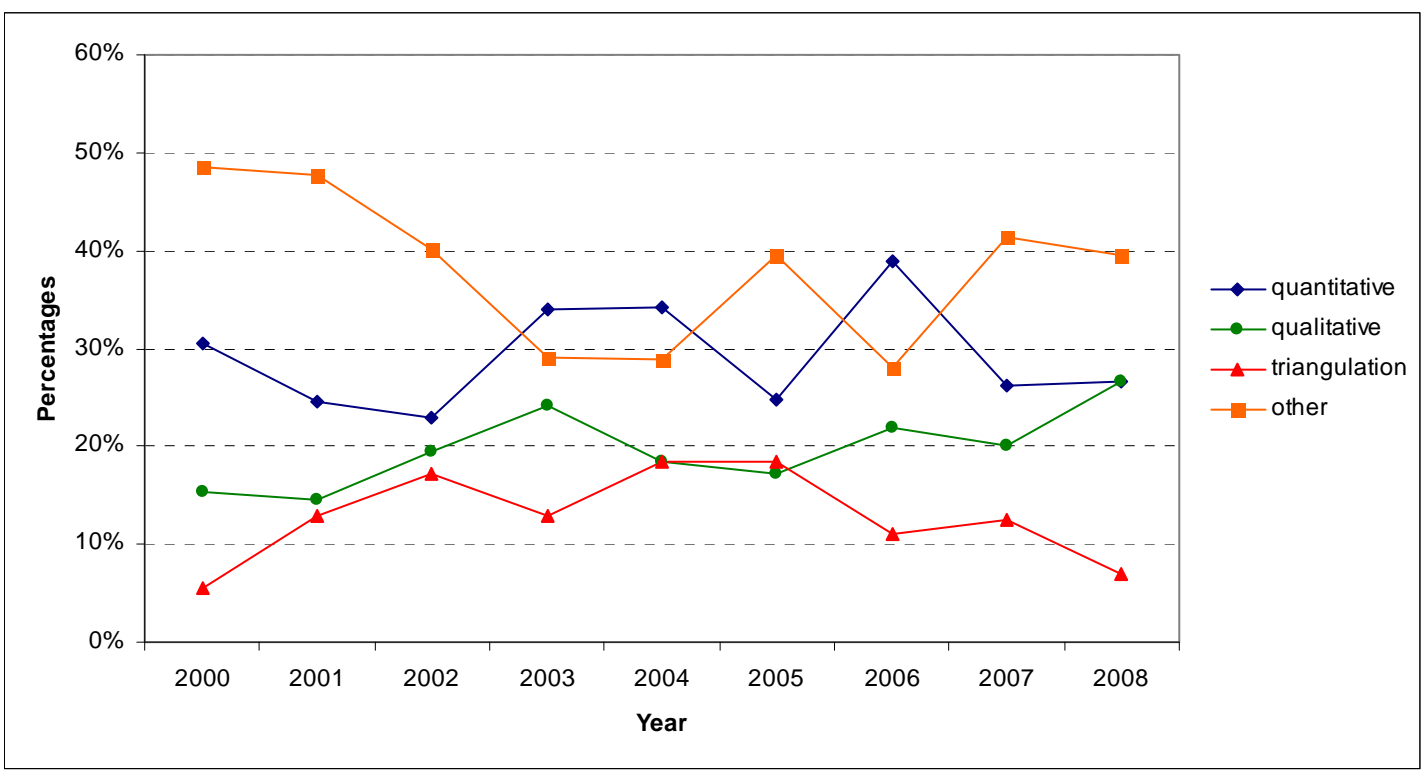

Figure 1. Frequencies regarding methodological approaches in studies published between 2000 and 2008.

Table 6

Frequency Tabulation of Methods used in Studies Published between 2000 and 2008

\begin{tabular}{lllllll}
\hline Year & & $\begin{array}{l}\text { Quanti- } \\
\text { tative }\end{array}$ & $\begin{array}{l}\text { Quali- } \\
\text { tative }\end{array}$ & $\begin{array}{l}\text { Triangu- } \\
\text { lation }\end{array}$ & Other & Total \\
\hline 2000 & Count & 22 & 11 & 4 & 35 & 72 \\
& \% within year & $30.6 \%$ & $15.3 \%$ & $5.6 \%$ & $48.6 \%$ & $100.0 \%$ \\
2001 & Count & 17 & 10 & 9 & 33 & 69 \\
& \% within year & $24.6 \%$ & $14.5 \%$ & $13.0 \%$ & $47.8 \%$ & $100.0 \%$ \\
2002 & Count & 20 & 17 & 15 & 35 & 87 \\
& \% within year & $23.0 \%$ & $19.5 \%$ & $17.2 \%$ & $40.2 \%$ & $100.0 \%$ \\
2003 & Count & 21 & 15 & 8 & 18 & 62 \\
& \% within year & $33.9 \%$ & $24.2 \%$ & $12.9 \%$ & $29.0 \%$ & $100.0 \%$ \\
2004 & Count & 26 & 14 & 14 & 22 & 76 \\
& \% within year & $34.2 \%$ & $18.4 \%$ & $18.4 \%$ & $28.9 \%$ & $100.0 \%$ \\
2005 & Count & 20 & 14 & 15 & 32 & 81 \\
& \% within year & $24.7 \%$ & $17.3 \%$ & $18.5 \%$ & $39.5 \%$ & $100.0 \%$ \\
2006 & Count & 32 & 18 & 9 & 23 & 82 \\
& \% within year & $39.0 \%$ & $22.0 \%$ & $11.0 \%$ & $28.0 \%$ & $100.0 \%$ \\
2007 & Count & 21 & 16 & 10 & 33 & 80 \\
& \% within year & $26.3 \%$ & $20.0 \%$ & $12.5 \%$ & $41.3 \%$ & $100.0 \%$ \\
2008 & Count & 23 & 23 & 6 & 34 & 86 \\
& \% within year & $26.7 \%$ & $26.7 \%$ & $7.0 \%$ & $39.5 \%$ & $100.0 \%$ \\
\hline \multirow{2}{*}{ Total } & Count & 202 & 138 & 90 & 265 & 695 \\
& \% within year & $29.1 \%$ & $19.9 \%$ & $12.9 \%$ & $38.1 \%$ & $100.0 \%$ \\
\hline
\end{tabular}


Research into issues on the macro level (distance education systems and theories) is very descriptive, e.g., research area 3 (distance teaching systems and institutions, 77.4\%), or research area 1 (issues of access, equity and ethics, 74.2\%). As could be expected, the highest percentage of theoretical papers was found under research area 4 on theories and models of distance education (79.2\%). The highest frequency of qualitative approaches can be reported for research area 14 (interaction and communication in learning communities, 33.6\%). A large number of quantitative studies are carried out in research area 12 (quality assurance, e.g., development and application of instruments for program evaluation, analysis of drop-out, completion/noncompletion in distance learning programs, etc., 53.7\%), and in research area 15 (learner characteristics, e.g., studies on learning styles, learner preferences, etc., 53.1\%). 
Table 7

Frequency Tabulation of Methods by Research Area $(N=695)$

\begin{tabular}{|c|c|c|c|c|c|c|}
\hline $\begin{array}{l}\mathbf{R} . \\
\text { area* }\end{array}$ & & Quantitative & Qualitative & Triangulation & Other & Total \\
\hline \multirow[t]{2}{*}{1} & Count & 3 & 3 & 2 & 23 & 31 \\
\hline & $\%$ within R. area & $9.7 \%$ & $9.7 \%$ & $6.5 \%$ & $74.2 \%$ & $100.0 \%$ \\
\hline \multirow[t]{2}{*}{2} & Count & 1 & 4 & 0 & 8 & 13 \\
\hline & $\%$ within $\mathrm{R}$. area & $7.7 \%$ & $30.8 \%$ & $.0 \%$ & $61.5 \%$ & $100.0 \%$ \\
\hline \multirow[t]{2}{*}{3} & Count & 8 & 4 & 2 & 48 & 62 \\
\hline & $\%$ within $\mathrm{R}$. area & $12.9 \%$ & $6.5 \%$ & $3.2 \%$ & $77.4 \%$ & $100.0 \%$ \\
\hline \multirow[t]{2}{*}{4} & Count & 1 & 3 & 1 & 19 & 24 \\
\hline & $\%$ within $\mathrm{R}$. area & $4.2 \%$ & $12.5 \%$ & $4.2 \%$ & $79.2 \%$ & $100.0 \%$ \\
\hline \multirow[t]{2}{*}{5} & Count & 5 & 1 & 0 & 7 & 13 \\
\hline & $\%$ within $\mathrm{R}$. area & $38.5 \%$ & $7.7 \%$ & $.0 \%$ & $53.8 \%$ & $100.0 \%$ \\
\hline \multirow[t]{2}{*}{6} & Count & 4 & 1 & 2 & 11 & 18 \\
\hline & $\%$ within $\mathrm{R}$. area & $22.2 \%$ & $5.6 \%$ & $11.1 \%$ & $61.1 \%$ & $100.0 \%$ \\
\hline \multirow[t]{2}{*}{7} & Count & 4 & 0 & 1 & 7 & 12 \\
\hline & $\%$ within $\mathrm{R}$. area & $33.3 \%$ & $.0 \%$ & $8.3 \%$ & $58.3 \%$ & $100.0 \%$ \\
\hline \multirow[t]{2}{*}{8} & Count & 7 & 6 & 4 & 31 & 48 \\
\hline & $\%$ within $\mathrm{R}$. area & $14.6 \%$ & $12.5 \%$ & $8.3 \%$ & $64.6 \%$ & $100.0 \%$ \\
\hline \multirow[t]{2}{*}{9} & Count & 5 & 3 & 1 & 4 & 13 \\
\hline & $\%$ within R. area & $38.5 \%$ & $23.1 \%$ & $7.7 \%$ & $30.8 \%$ & $100.0 \%$ \\
\hline \multirow[t]{2}{*}{10} & Count & 10 & 10 & 7 & 14 & 41 \\
\hline & $\%$ within $\mathrm{R}$. area & $24.4 \%$ & $24.4 \%$ & $17.1 \%$ & $34.1 \%$ & $100.0 \%$ \\
\hline \multirow[t]{2}{*}{11} & Count & 7 & 6 & 2 & 8 & 23 \\
\hline & $\%$ within $\mathrm{R}$. area & $30.4 \%$ & $26.1 \%$ & $8.7 \%$ & $34.8 \%$ & $100.0 \%$ \\
\hline \multirow[t]{2}{*}{12} & Count & 22 & 5 & 5 & 9 & 41 \\
\hline & $\%$ within $\mathrm{R}$. area & $53.7 \%$ & $12.2 \%$ & $12.2 \%$ & $22.0 \%$ & $100.0 \%$ \\
\hline \multirow[t]{2}{*}{13} & Count & 31 & 26 & 21 & 43 & 121 \\
\hline & $\%$ within $\mathrm{R}$. area & $25.6 \%$ & $21.5 \%$ & $17.4 \%$ & $35.5 \%$ & $100.0 \%$ \\
\hline \multirow[t]{2}{*}{14} & Count & 34 & 41 & 27 & 20 & 122 \\
\hline & $\%$ within $\mathrm{R}$. area & $27.9 \%$ & $33.6 \%$ & $22.1 \%$ & $16.4 \%$ & $100.0 \%$ \\
\hline \multirow[t]{2}{*}{15} & Count & 60 & 25 & 15 & 13 & 113 \\
\hline & $\%$ within R. area & $53.1 \%$ & $22.1 \%$ & $13.3 \%$ & $11.5 \%$ & $100.0 \%$ \\
\hline \multirow[t]{2}{*}{ Total } & Count & 202 & 138 & 90 & 265 & 695 \\
\hline & $\%$ of Total & $29.1 \%$ & $19.9 \%$ & $12.9 \%$ & $38.1 \%$ & $100.0 \%$ \\
\hline
\end{tabular}

* 1=Access, equity and ethics; $2=$ Globalisation of education and cross-cultural aspects; $3=$ Distance teaching systems and institutions; 4=Theories and models; 5=Research methods in distance education and knowledge transfer; 6=Management and organisation; 7=Costs and benefits; 8=Educational technology; 9=Innovation and change; $10=$ Professional development and faculty support; 11=Learner support services; 12=Quality assurance; 13=Instructional design; 14=Interaction and communication in learning communities; 15=Learner characteristics 


\section{Authorship Patterns and Reference Characteristics}

\section{Collaboration.}

With 15 research areas on three broad levels, as described in the Classification of Research Areas section, the complexity of the distance education discipline is enormous, and it continues to grow with the application of new and emerging information and communication technologies and their implications for educational systems and organizational change. Researchers are more and more involved in international collaborative projects. This phenomenon has accelerated during the last decade through the massive proliferation of computer-mediated communication and the development of new web applications which facilitate collaboration, social interaction, and negotiation of meaning (e.g., via social software or Web 2.0 applications). As an indicator of the extent of collaboration among researchers, the number of contributors per paper was analyzed.

Table 8

Frequency Tabulation Regarding the Number of Authors by Year (Percentages in Brackets)

\begin{tabular}{|c|c|c|c|c|c|c|c|c|c|}
\hline \multirow[t]{2}{*}{ Year } & \multicolumn{9}{|c|}{ Number of author(s) } \\
\hline & 1 & 2 & 3 & 4 & 5 & 6 & 7 & 8 & $\begin{array}{l}\text { Total } \\
\text { (2 to 8) }\end{array}$ \\
\hline 2000 & $\begin{array}{l}35 \\
(48.6)\end{array}$ & 25 & 8 & 2 & 1 & 0 & 1 & 0 & $\begin{array}{l}37 \\
(52.4)\end{array}$ \\
\hline 2001 & $\begin{array}{l}34 \\
(49.3)\end{array}$ & 15 & 13 & 2 & 3 & 2 & 0 & 0 & $\begin{array}{l}69 \\
(50.7)\end{array}$ \\
\hline 2002 & $\begin{array}{l}42 \\
(48.3)\end{array}$ & 21 & 16 & 4 & 2 & 1 & 0 & 1 & $\begin{array}{l}87 \\
(51.7)\end{array}$ \\
\hline 2003 & $\begin{array}{l}27 \\
(43.6)\end{array}$ & 24 & 6 & 1 & 3 & 1 & 0 & 0 & $\begin{array}{l}62 \\
(56.5)\end{array}$ \\
\hline 2004 & $\begin{array}{l}38 \\
(50.0)\end{array}$ & 22 & 10 & 6 & 0 & 0 & 0 & 0 & $\begin{array}{l}76 \\
(50.0)\end{array}$ \\
\hline 2005 & $\begin{array}{l}37 \\
(45.7)\end{array}$ & 25 & 11 & 5 & 3 & 0 & 0 & 0 & $\begin{array}{l}81 \\
(54.3)\end{array}$ \\
\hline 2006 & $\begin{array}{l}29 \\
(35.4)\end{array}$ & 31 & 12 & 6 & 3 & 1 & 0 & 0 & $\begin{array}{l}82 \\
(64.6)\end{array}$ \\
\hline 2007 & $\begin{array}{l}28 \\
(35.0)\end{array}$ & 32 & 12 & 4 & 3 & 1 & 0 & 0 & $\begin{array}{l}80 \\
(65.0)\end{array}$ \\
\hline 2008 & $\begin{array}{l}37 \\
(43.0)\end{array}$ & 26 & 16 & 4 & 3 & 0 & 0 & 0 & $\begin{array}{l}49 \\
(57.0)\end{array}$ \\
\hline Total & $\begin{array}{l}307 \\
(44.2)\end{array}$ & 221 & 104 & 34 & 21 & 6 & 1 & 1 & $\begin{array}{l}388 \\
(55.8)\end{array}$ \\
\hline
\end{tabular}

From 2000 to 2008, the percentage of single author articles decreased while the percentage of multiple author articles increased. There is a significant positive trend for multiple author articles 
(Spearman's $\rho=.70, p<.05$ ) and a significant negative trend for single author articles (Spearman's $\rho=-.73, p<.05$ ).

This positive trend since 2000 towards collaboration in distance education research is supported by the fact that Mishra (1997) reported a much lower percentage of multiple author papers of $38.5 \%$ for the period between 1991 and $1996(N=361$ articles $)$.

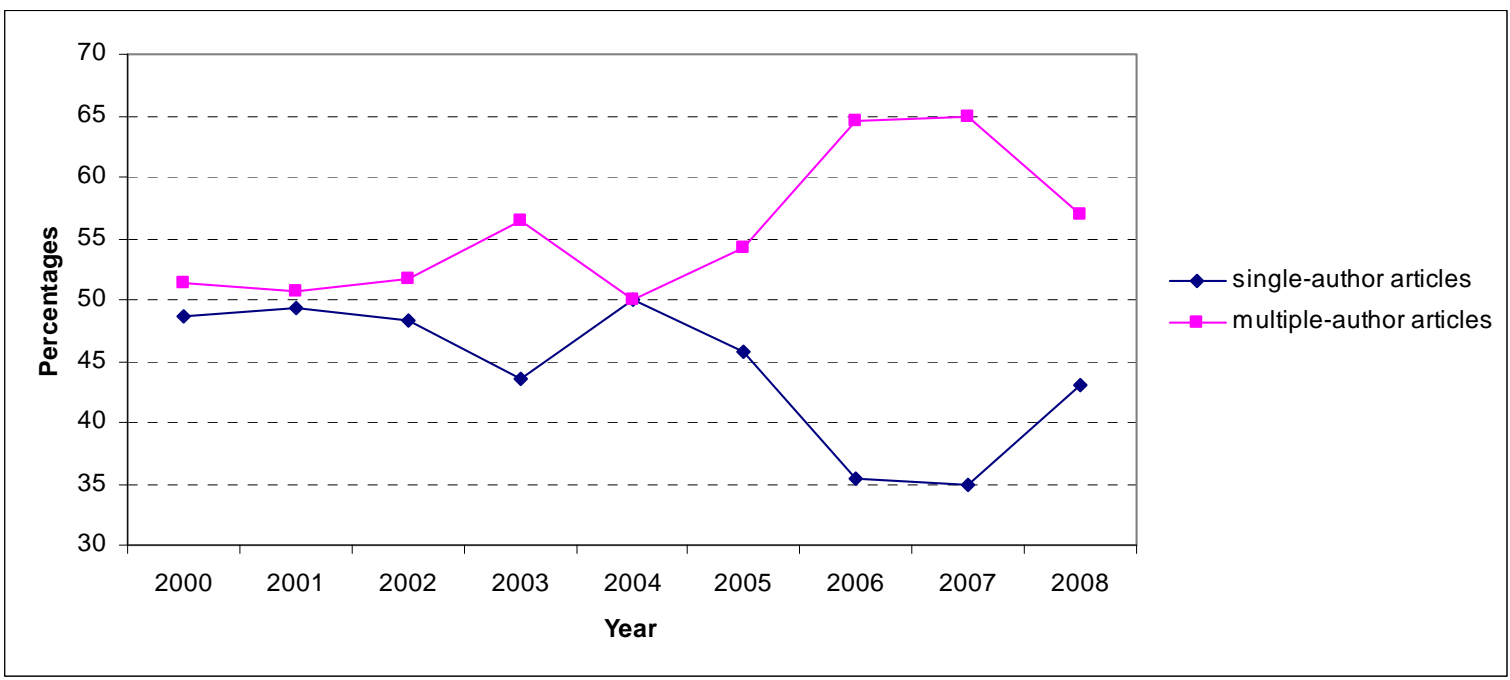

Figure 2. Articles contributed by one author and multiple authors between 2000 and $2008(N=$ 695)

\section{Leading contributors.}

The total number of different authors who contributed to the 695 articles in this study was 1138. Table 9 lists the 48 authors who contributed to at least three articles. They are from Australia (5), Canada (17), China (5), Israel (2), Japan/South Korea (1), New Zealand (1), UK (8), and USA (9). Canada is very successful in distance education research, with 17 leading contributors coming from this country. Nine of these 17 researchers are affiliated with Athabasca University. 
Table 9

Leading Contributors and Number of their Published Articles

\begin{tabular}{llll}
\hline Jeong, Allan C. (USA) & 7 & Zhang, Wei-Yuan (China) & 4 \\
Conrad, Dianne (Canada) & 6 & Abrami, Philip C. (Canada) & 3 \\
Fahy, Patrick J. (Canada) & 6 & Ally, Mohamed (Canada) & 3 \\
Latchem, Colin (Australia) & 6 & Anderson, Bill (New Zealand) & 3 \\
Stacey, Elizabeth (Australia) & 6 & Baumann, Uwe (UK) & 3 \\
Anderson, Terry (Canada) & 5 & Caspi, Avner (Israel) & 3 \\
Berge, Zane L. (USA) & 5 & Dennen, Vanessa P. (USA) & 3 \\
Gunawardena, Charlotte N. (USA) & 5 & Fung, Yvonne (China) & 3 \\
Kanuka, Heather (Canada) & 5 & Garrison, Randy (Canada) & 3 \\
Andrusyszyn, Mary-Anne (Canada) & 4 & Gorsky, Paul (Israel) & 3 \\
Bernard, Robert M. (Canada) & 4 & Kennepohl, Dietmar (Canada) & 3 \\
Bonk, Curtis J. (USA) & 4 & Lou, Yiping (USA) & 3 \\
Bourdages, Louise (Canada) & 4 & Mason, Robin (UK) & 3 \\
Bullen, Mark (Canada) & 4 & Moisey, Susan D. (Canada) & 3 \\
Cleveland-Innes, Martha (Canada) & 4 & Nunan, Ted (Australia) & 3 \\
Deschenes, A.-J. (Canada) & 4 & Rennie, Frank (UK) & 3 \\
Jung, Insung (South Korea/Japan) & 4 & Rosi Solé, Cristina (UK) & 3 \\
Kirkwood, Adrian (UK) & 4 & Rovai, Alfred P. (USA) & 3 \\
McGreal, Rory (Canada) & 4 & Shelley, Monica (UK) & 3 \\
Murphy, Elizabeth (Canada) & 4 & Shin, Namin (China) & 3 \\
Murphy, Karen L. (USA) & 4 & Simpson, Ormond (UK) & 3 \\
Ng, Kwok Chi (China) & 4 & Sims, Rod (Australia) & 3 \\
Smith, Peter J. (Australia) & 4 & Taplin, Margaret (China) & 3 \\
Wisher, Robert A. (USA) & 4 & Woodley, Alan (UK) & 3 \\
\hline
\end{tabular}

\section{Male and female researchers.}

The analysis in Table 10 depicts that 385 (55.4\%) of the first authors were men and $310(44.6 \%)$ were women. The results seem to confirm the stereotypical view that female researchers $(59.4 \%)$ are more likely than males $(40.6 \%)$ to choose qualitative methods or to combine quantitative and qualitative methods (females, 61.1\%). There is a highly significant association between gender and research methods: $\chi^{2}=35.34, d f=3, p<.001$. However, the association is modest at Cramer's V of .23 $(p<.001)$. 
Table 10

Cross Tabulation of Gender (First Author) and Research Methods

\begin{tabular}{llllll}
\hline & & Male & Female & Total \\
\hline Method & Quantitative & Count & 119 & 83 & 202 \\
& & \% within method & $58.9 \%$ & $41.1 \%$ & $100.0 \%$ \\
& Qualitative & Count & 56 & 82 & 138 \\
& & $\%$ within method & $40.6 \%$ & $59.4 \%$ & $100.0 \%$ \\
& \multirow{4}{*}{ Triangulation } & Count & 35 & 55 & 90 \\
& \multirow{4}{*}{ Other } & \% within method & $38.9 \%$ & $61.1 \%$ & $100.0 \%$ \\
& & Count & 175 & 90 & 265 \\
& & \% within method & $66.0 \%$ & $34.0 \%$ & $100.0 \%$ \\
\hline Total & & Count & 385 & 310 & 695 \\
& & \% of total & $55.4 \%$ & $44.6 \%$ & $100.0 \%$ \\
\hline
\end{tabular}

\section{Country-wise distribution of articles.}

For the analysis of the country-wise distribution of articles, the country of origin of the first author was taken into consideration (53 countries). Table 11 shows that the vast majority of articles (80.3\%) come from only five countries: USA, Canada, UK, Australia, and China. Given the national bias of journals, it is no wonder that journals tend to publish more from their own country of origin. For example, the stated intent of AJDE is to explore "the great new field of study, research, and practice that is distance education in the Americas" (Moore, 1987, p. 1). This goal is truly met: AJDE in particular, and also JDE, have a strong North American focus: $80.4 \%$ of papers published in AJDE and $71.1 \%$ of papers published in JDE are contributed by USAmerican or Canadian authors respectively. Koble and Bunker (1997) found that $69.8 \%$ of authors in AJDE between 1987 and 1995 were from the USA and 20.9\% were from Canada. Similar results are also reported in earlier studies by Calvert (1995) and Mishra (1997).

The most international journal is IRRODL with only $18.9 \%$ of authors from Canada, followed by DE with $20.5 \%$ of authors from Australia, and OL with $42.2 \%$ of authors from the UK. Papers published in IRRODL come from 34 different countries, followed by DE ( 25 countries), OL (24 countries), JDE (13 countries), and AJDE (only 7 countries). 
Table 11

Cross Tabulation of Countries (First Author) and Journals

\begin{tabular}{|c|c|c|c|c|c|c|c|c|}
\hline Country & OL & DE & AJDE & JDE & $\begin{array}{l}\text { IRR- } \\
\text { ODL }\end{array}$ & Total & $\%$ & $\begin{array}{l}\text { Cum. } \\
\% \\
\end{array}$ \\
\hline $1 \mathrm{USA}$ & 10 & 54 & $90^{*}$ & 14 & 41 & 209 & 30.1 & 30.1 \\
\hline 2 Canada & 12 & 12 & 16 & $81^{*}$ & $30^{*}$ & 155 & 22.3 & 52.4 \\
\hline $3 \mathrm{UK}$ & $65^{*}$ & 16 & 2 & 1 & 15 & 99 & 14.2 & 66.6 \\
\hline 4 Australia & 13 & $32^{*}$ & 0 & 3 & 18 & 66 & 9.5 & 76.1 \\
\hline 5 China & 17 & 5 & 0 & 2 & 5 & 29 & 4.2 & 80.3 \\
\hline 6 India & 5 & 3 & 0 & 2 & 2 & 12 & 1.7 & 82.0 \\
\hline 7 New Zealand & 4 & 3 & 0 & 0 & 3 & 10 & 1.4 & 83.5 \\
\hline 8 Israel & 3 & 0 & 1 & 2 & 3 & 9 & 1.3 & 84.7 \\
\hline 9 South Africa & 5 & 2 & 0 & 0 & 1 & 8 & 1.2 & 85.9 \\
\hline 10 Nigeria & 2 & 0 & 0 & 0 & 4 & 6 & 0.9 & 86.8 \\
\hline 11 Norway & 1 & 0 & 0 & 0 & 4 & 5 & 0.7 & 87.5 \\
\hline 12 Netherlands & 1 & 3 & 0 & 0 & 1 & 5 & 0.7 & 88.2 \\
\hline 13 South Korea & 1 & 1 & 1 & 0 & 2 & 5 & 0.7 & 88.9 \\
\hline 14 Belgium & 0 & 1 & 0 & 3 & 0 & 4 & 0.6 & 89.5 \\
\hline 15 Brazil & 1 & 0 & 1 & 0 & 2 & 4 & 0.6 & 90.1 \\
\hline 16 Germany & 0 & 0 & 0 & 1 & 3 & 4 & 0.6 & 90.6 \\
\hline 17 Japan & 3 & 0 & 0 & 0 & 1 & 4 & 0.6 & 91.2 \\
\hline 18 Philippines & 0 & 2 & 0 & 0 & 2 & 4 & 0.6 & 91.8 \\
\hline 19 Spain & 0 & 0 & 0 & 0 & 4 & 4 & 0.6 & 92.4 \\
\hline 20 Botswana & 1 & 0 & 0 & 0 & 2 & 3 & 0.4 & 92.8 \\
\hline 21 France & 0 & 0 & 0 & 3 & 0 & 3 & 0.4 & 93.2 \\
\hline 22 Mexico & 1 & 2 & 0 & 0 & 0 & 3 & 0.4 & 93.7 \\
\hline 23 Sweden & 0 & 1 & 0 & 0 & 2 & 3 & 0.4 & 94.1 \\
\hline 24 Taiwan & 0 & 2 & 0 & 0 & 1 & 3 & 0.4 & 94.5 \\
\hline 25 Tanzania & 3 & 0 & 0 & 0 & 0 & 3 & 0.4 & 95.0 \\
\hline 26 Cambodia & 0 & 2 & 0 & 0 & 0 & 2 & 0.3 & 95.3 \\
\hline 27 Greece & 0 & 0 & 0 & 0 & 2 & 2 & 0.3 & 95.5 \\
\hline 28 Italy & 0 & 1 & 0 & 1 & 0 & 2 & 0.3 & 95.8 \\
\hline 29 Malaysia & 2 & 0 & 0 & 0 & 0 & 2 & 0.3 & 96.1 \\
\hline 30 Singapore & 0 & 2 & 0 & 0 & 0 & 2 & 0.3 & 96.4 \\
\hline 31 Turkey & 0 & 1 & 0 & 1 & 0 & 2 & 0.3 & 96.7 \\
\hline 32 Argentina & 0 & 1 & 0 & 0 & 0 & 1 & 0.1 & 96.8 \\
\hline 33 Bhutan & 0 & 1 & 0 & 0 & 0 & 1 & 0.1 & 97.0 \\
\hline 34 Colombia & 0 & 0 & 0 & 0 & 1 & 1 & 0.1 & 97.1 \\
\hline 35 Costa Rica & 1 & 0 & 0 & 0 & 0 & 1 & 0.1 & 97.3 \\
\hline 36 Cyprus & 0 & 1 & 0 & 0 & 0 & 1 & 0.1 & 97.4 \\
\hline 37 Denmark & 1 & 0 & 0 & 0 & 0 & 1 & 0.1 & 97.6 \\
\hline 38 Fiji Islands & 0 & 1 & 0 & 0 & 0 & 1 & 0.1 & 97.7 \\
\hline
\end{tabular}




\begin{tabular}{lllllllll}
\hline 39 Iceland & 0 & 0 & 0 & 0 & 1 & 1 & 0.1 & 97.8 \\
40 Indonesia & 0 & 0 & 0 & 0 & 1 & 1 & 0.1 & 98.0 \\
41 Ireland & 1 & 0 & 0 & 0 & 0 & 1 & 0.1 & 98.1 \\
42 Korea & 0 & 0 & 0 & 0 & 1 & 1 & 0.1 & 98.3 \\
43 Mauritius & 0 & 0 & 0 & 0 & 1 & 1 & 0.1 & 98.4 \\
44 Mongolia & 0 & 1 & 0 & 0 & 0 & 1 & 0.1 & 98.6 \\
45 Oman & 0 & 0 & 0 & 0 & 1 & 1 & 0.1 & 98.7 \\
46 Portugal & 0 & 0 & 0 & 0 & 1 & 1 & 0.1 & 98.8 \\
47 Puerto Rico & 0 & 0 & 1 & 0 & 0 & 1 & 0.1 & 99.0 \\
48 Rwanda & 0 & 0 & 0 & 0 & 1 & 1 & 0.1 & 99.1 \\
49 Switzerland & 0 & 1 & 0 & 0 & 0 & 1 & 0.1 & 99.4 \\
50 Thailand & 1 & 0 & 0 & 0 & 0 & 1 & 0.1 & 99.6 \\
51 Ukraine & 0 & 0 & 0 & 0 & 1 & 1 & 0.1 & 99.7 \\
52 Venezuela & 0 & 0 & 0 & 0 & 1 & 1 & 0.1 & 99.9 \\
53 Zambia & 0 & 0 & 0 & 0 & 1 & 1 & 0.1 & 100.0 \\
& 154 & 156 & 112 & 114 & 159 & 695 & 100 & \\
\hline No. of countries & 24 & 25 & 8 & 13 & 33 & & & \\
by journal & & & & & & & & \\
\hline *country of origin of the journal & & & & & & &
\end{tabular}

*country of origin of the journal

\section{Number of references.}

In 1985 Michael G. Moore, the editor of AJDE, lamented the lack of references to previous research and theoretical frameworks: "I believe the convention of reporting previous research as preface to current research is too neglected today" (Moore, 1985, p. 37).

The incidence of unreferenced articles and the number of references per article is taken as an indicator of the scholarliness of a journal (cf. Cline, 1982, p. 210; Mishra, 1997). Articles providing fewer than 10 references imply that "scholarship does not exist but is irrelevant or exists relevantly but is unknown" (Price, 1970, p. 8). Taking this as a benchmark, as was to be expected, all journals under review are on a high academic level, with a mean of 29 references per article. During the period of 2000 to 2008, only one paper out of 695 was published without any references in AJDE (Osiakwan \& Wright. 2001). The record holder is McGreal (2004) with 128 references in a paper in IRRODL on copyright issues.

However, this point should not be pushed too hard. We do not claim that papers with 20 references are more scholarly than those with only 15, or that all articles with 20 references are of similar scholarliness. 
Table 12

Number of References per Article by Journal

\begin{tabular}{lllllll}
\hline No. of references & OL & DE & AJDE & JDE & IRRODL & Total \\
\hline $0-5$ & 4 & 2 & 4 & 2 & 1 & 4 \\
$6-10$ & 16 & 6 & 5 & 8 & 13 & 16 \\
$11-15$ & 24 & 11 & 9 & 11 & 17 & 24 \\
$16-20$ & 28 & 13 & 23 & 10 & 20 & 28 \\
$21-25$ & 18 & 25 & 21 & 16 & 17 & 18 \\
$26-30$ & 14 & 21 & 15 & 23 & 20 & 14 \\
$31-35$ & 12 & 22 & 9 & 12 & 16 & 12 \\
$35-40$ & 15 & 10 & 14 & 6 & 11 & 15 \\
$41-45$ & 5 & 16 & 4 & 7 & 9 & 5 \\
$46-50$ & 6 & 6 & 1 & 10 & 10 & 6 \\
$51-55$ & 5 & 7 & 4 & 6 & 12 & 5 \\
$56-60$ & 2 & 6 & 2 & 2 & 4 & 2 \\
$61-65$ & 3 & 5 & 0 & 0 & 4 & 3 \\
$66-70$ & 0 & 3 & 0 & 0 & 2 & 0 \\
$71-75$ & 1 & 2 & 0 & 0 & 0 & 1 \\
$76-80$ & 0 & $1^{\mathrm{b}}$ & 0 & 0 & 0 & 0 \\
$81-85$ & 0 & 0 & 0 & $1^{\mathrm{d}}$ & 1 & 0 \\
$86-90$ & $1^{\mathrm{a}}$ & 0 & 0 & 0 & 1 & 1 \\
$91-95$ & 0 & 0 & $1^{\mathrm{c}}$ & 0 & 0 & 0 \\
$126-130$ & 0 & 0 & 0 & 0 & $1^{\mathrm{e}}$ & 0 \\
\hline Mean & 26 & 33 & 27 & 29 & 31 & 29 \\
\hline a 89 & 0 & & & & \\
\hline
\end{tabular}

${ }^{\mathrm{a}} 89$ references, ${ }^{\mathrm{b}} 80$ references, ${ }^{\mathrm{c}} 92$ references, ${ }^{\mathrm{d}} 83$ references, ${ }^{\mathrm{e}} 128$ references

\section{Conclusions and Implications for Future Fesearch}

This study examined (1) research areas in distance education, trends, priority areas, and gaps in distance education research; (2) research methods in distance education; and (3) authorship patterns. The results of this review convey certain implications for future research in distance education.

Major findings of this study may be summarized as follows:

- Research in distance education is dominated by studies that focus on interaction and communication patterns in computer-mediated communication, instructional design issues, learner characteristics, and educational technology.

- In terms of research methods, the only discernible trend was found for qualitative research methods, with a modest upward trend on a low percentage level. Maybe researchers in the field have taken note of those who advocate more qualitative studies to capture a deeper and richer range of data (cf. Minnes, 1985; Saba 2000). 
- The AJDE clearly prefers to publish quantitative studies; whereas, DE accepted the highest number of qualitative studies, and JDE published the highest number of papers that followed a mixed method design.

- More than $80 \%$ of all articles were contributed by authors from only five countries: USA, Canada, UK, Australia, and China. The first authors of the 695 articles under review came from 54 different countries. Interestingly, the journals publish more from their own country of origin. The most international journal is IRRODL with only $18.9 \%$ of authors coming from Canada; whereas, AJDE has a strong North American bias with over $80 \%$ of authors from the USA and Canada.

- A significant trend was found towards more collaboration among researchers in distance education. In the period between 2000 and 2008, the proportion of single-author papers was $44.2 \%$ compared to $61.5 \%$ of 361 articles published between 1991 and 1996 that were reviewed by Mishra (1997).

\section{So Quo Vadis?}

According to the experts' opinion in the Delphi study (Zawacki-Richter, 2009), there is a great need for more research on the role of culture and cultural differences in global distance learning programmes. Furthermore, co-operation among institutions should receive much more attention, including the impact of cultural differences on leadership and culturally complex student support systems, and there is a need for comparative research on distance learning systems (macro level). A lot of work still needs to be done on the meso level: In particular, experts on the panel highlighted aspects referring to leadership in distance education and strategy, management of change and innovation, costs, organizational development and infrastructure for online student and faculty support, professional development, and quality assurance. The experts claimed that empirical evidence is lacking on the pedagogical opportunities that Web 2.0 applications, mobile devices, and synchronous tools afford for teaching, learning, and assessment.

This review of 695 articles published in five leading distance education research journals confirms the results of the pre-study. It reveals a strong imbalance between the three research levels. Distance education research is highly dominated by issues that refer to the micro perspective (teaching and learning in distance education), with over $50 \%$ of all articles focusing on interaction and communication in learning communities, instructional design, and learner characteristics. As anticipated according to the results of the pre-study, those areas that were said to require much more attention take the last three places (globalisation of education and crosscultural aspects, innovation and change, and costs and benefits) in the ranking of research areas with regard to the frequency of articles (Table 3).

A possible interpretation for this imbalance is that the selection of research themes might follow practical considerations, especially with regard to the availability of data. Of course, the analysis of interaction patterns in computer-mediated communication is a very interesting topic and the text-based data of synchronous communication in online conferences is saved in databases of learning management systems and is therefore readily available. In contrast, it is not surprising 
that educational institutions, as competitors in the global education market, are unwilling to freely share business models and data on their budgets and costs.

However, the dearth of articles dealing with issues especially on the meso level (management, organization, and technology) is disappointing. In order to guide practice, practitioners in the field should not rely on under-informed trial and error, but on sound research and empirical investigation on the effectiveness of managerial interventions for education innovation, diversity management, student and faculty support, quality assurance, course design, and intercultural communication. 


\section{References}

Bakeman, R., \& Gottman, J. M. (1997). Observing interaction - an introduction to sequential analysis. Cambridge: Cambridge University Press.

Berge, Z., \& Mrozowski, S. (2001). Review of research in distance education. American Journal of Distance Education, 15(3). 5-19.

Bernard, R. M., Abrami. P. C., Lou. Y., \& Borokhovski, E. (2004). A methodological morass? How we can improve quantitative research in distance education. Distance Education, 25(2), 175-198.

Calvert, J. (1995). Mapping knowledge in distance education. In D. Sewart (Ed.), One World. Many Voices: Quality in Open and Distance learning - 17th World Conference Proceedings (pp. 384-388). Milton Keynes: ICDE.

Cohen, J. (1960). A coefficient of agreement for nominal scales. Educational and Psychological Measurement, 20, 37-46.

Charlton, J. R. H. (2004). Delphi technique. In M. S. Lewis-Beck, A. Bryman \& T. F. Liao (Eds.), The SAGE encyclopedia of social science research methods (Vol. 1). Thousand Oaks: Sage.

Cline, G. S. (1982). College and research libraries: Its first forty years. College and Research Libraries, 43(3), 208-232.

Fleiss, J. L. (1981). Statistical methods for rates and proportions. New York: Wiley.

Garrison. D. R., \& Shale, D. (1994). Methodological issues: Philosophical differences and complementary methodologies. In D. R. Garrison (Ed.), Research perspectives in adult education (pp. 17-37). Florida: Krieger.

Grant. L., Ward. K. B., \& Rong, X. L. (1987). Is there an association between gender and methods in sociological research? American Sociological Review, 52, 856-862.

Isaac, S., \& Michael, W. (1995). Handbook in research and evaluation. San Diego: Educational and Industrial Testing Services.

Koble, M. A., \& Bunker, E. L. (1997). Trends in research and practice: An examination of The American Journal of Distance Education, 1987-1995. American Journal of Distance Education, 11(2), 19-38. 
Lee, Y., Driscoll, M. P., \& Nelson, D. W. (2004). The past, present, and future of research in distance education: Results of a content analysis. American Journal of Distance Education, 18(4), 225-241.

McGreal, R. (2004). Stealing the goose: Copyright and learning. International Review of Research in Open and Distance Learning, 5(3).

Minnes, J. R. (1985). Ethnography, case study, grounded theory, and distance education research. Distance Education, 6(2), 189-198.

Mishra, S. (1998). Distance education research: A review of its structure, methodological issues and priority areas. Indian Journal of Open Learning, 7(3), 267-282.

Mishra. S. (1997). A critical analysis of periodical literature in distance education. Indian Journal of Open Learning, 6(1\&2), 39-54.

Moore, M. G. (1987). Words of welcome and intent. The American Journal of Distance Education, 1(1), 1-5.

Moore, M. G. (1985). Some observations on current research in distance education. Epistolodidaktika, 1, 35-62.

Neumann, W. L. (2007). Social research methods: Qualitative and quantitative approaches. Boston: Pearson.

Panda, S. (1992). Distance educational research in India: Stock-taking, concerns and prospects. Distance Education, 13(2), 309-326.

Osiakwan, C., \& Wright, D. (2001). Distance training for operating equipment: A cost-benefit and return-on-investment analysis. American Journal of Distance Education, 15(1), 6979.

Perraton, H. (2000). Rethinking the research agenda. International Review of Research in Open and Distance Learning, 1(1).

Price, D. J. (1970). Citation measure of hard science, soft science, technology and non-science. In C. E. Nelson (Ed.), Communication among scientists and engineers (pp. 3-22). Lexington: Heth Lexington Books.

Rourke, L., \& Szabo, M. (2002). A content analysis of the Journal of Distance Education 19862001. Journal of Distance Education, 17(1), 63-74.

Saba, F. (2000). Research in distance education: A status report. International Review of Research in Open and Distance Learning, 1(1). 
Scriven. B. (1991). Ten years of 'distance education'. Distance Education, 12(1), 137-153.

Zawacki-Richter, O. (2009). Research areas in distance education: A Delphi study. International Review of Research in Open and Distance Learning, 10(3). 


\section{Appendix References of Sample Studies (Table 2)}

Al-Harthi, A. S. (2005). Distance higher education experiences of Arab Gulf students in the United States: A cultural perspective. International Review of Research in Open and Distance Learning, 6(3), 1-14.

Bernard, R. M., Abrami. P. C., Lou. Y., \& Borokhovski, E. (2004). A methodological morass? How we can improve quantitative research in distance education. Distance Education, 25(2), 175-198.

Beyth-Maron,. R., Harpaz-Gorodeisky, G., Bar-Haim, A., \& Godder, E. (2006). Identification, job satisfaction and work motivation among tutors and the Open University of Israel. International Review of Research in Open and Distance Learning, 7(2), 1-13.

Dearnley, C., \& Matthew, B. (2000). A group of nurses experience open learning: Exploring the impact. Open Learning, 15(2), 191-206.

Garrison. D. R., Anderson, T., \& Archer, W. (2001). Critical thinking, cognitive presence, and computer conferencing in distance education. American Journal of Distance Education, 15(1), 7-23.

Giguère, L. (2007). Benchmarking course completion rates: A method with an example from the British Columbia Open University. Journal of Distance Education, 22(1), 73-86.

Jeong, A. (2006). Gender interaction patterns and gender participation in computer-supported collaborative argumentation. American Journal of Distance Education, 20(4), 195-210.

Jones, J. G. (2008). Issues and concerns of directors of postsecondary distance learning programs regarding online methods and technologies. American Journal of Distance Education, 22(1), 46-56.

Jung, I. (2005). Cost-effectiveness of online teacher training. Open Learning, 20(2), 131-146.

Lara, L., Howell, R., Dominguez, J., \& Navarro, J. (2001). Synchronous and asynchronous interactions of bilingual Hispanic pre- and in-service teachers in distance learning. American Journal of Distance Education, 15(3), 50-67.

Lee, M. J. W., \& Chan, A. (2007). Pervasive, lifestyle-integrated mobile learning for distance learners: An analysis and unexpected results from a podcasting study. Open Learning, 22(3), 201-218.

Mishra, S. (2005). Roles and competencies of academic counsellors in distance education. Open Learning, 20(2), 147-159. 
Moisey, S. D., Neu. C., \& Cleveland-Innes, M. (2008). Community building and computermediated conferencing. Journal of Distance Education, 22(2), 15-42.

Morgan, J., Rawlinson, M., \& Weaver, M. (2006). Facilitating online reflective learning for health and social care professionals. Open Learning, 21(2), 167-176.

Muilenburg, L. Y., \& Berge. Z. L. (2005). Student barriers to online learning: A factor analytic study. Distance Education, 26(1), 29-48.

Rye, S. A., \& Zubaidah, I. (2008). Distance education and the complexity of accessing the Internet. Open Learning, 23(2), 95-102.

Shea, P., Pickett, A., \& Sau Li, C. (2005). Increasing access to higher education: A study of the diffusion of online teaching among 913 college faculty. International Review of Research in Open and Distance Learning, 6(2), 1-27.

Wang, T. (2005). Tensions in learner support and tutor support in tertiary web-based English language education in China. International Review of Research in Open and Distance Learning, 6(3), 1-18.

Williams, P. E. (2003). Roles and competencies for distance education programs in higher education institutions. American Journal of Distance Education, 17(1), 45-57.

Zhang, W.-Y., \& Shin, N. (2002). Imported or indigenous? A comparative study of three open and distance education models in mainland China, India and Hong Kong. Open Learning, 17(2), 167-176.

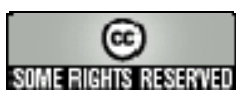

